\title{
Development of an optical tyrosinase biosensor (TCA) for detection of "Parathion-Methyl"
}

\author{
Ilker Polatoğlu \\ Department of Bioengineering, Manisa Celal Bayar University Faculty of Engineering, Manisa, Turkey, and \\ Fehime Cakıcıoglu Ozkan \\ Department of Chemical Engineering, Izmir Yuksek Teknoloji Enstitusu, Urla, Turkey
}

\begin{abstract}
Purpose - This paper aims to present a novel and cost-effective optical biosensor design by simple preparation method for detection of "parathionmethyl," which is a model pesticide pose to public health and the environment.

Design/methodology/approach - The optical enzyme biosensor (TCA) for detection of pesticide "parathion-methyl" was developed on the basis of immobilization of tyrosinase enzyme on chitosan film by adsorption technique. The analytic performance of TCA was investigated by measuring its activity with Ultraviolet (UV) visible spectrophotometer.

Findings - Uniform porous network structure and protonated groups of chitosan film provided a microenvironment for tyrosinase immobilization evident from Fourier transform infrared (FTIR) spectroscopy and Atomic Force Microscopy analysis. TCA has a wide linear detection range $(0-1.03 \mu \mathrm{M})$ with high correlation coefficient and it can detect the parathion-methyl concentration as low as $159 \mathrm{nM}$ by noncompetitive inhibition kinetics. Using the TCA sensor both for ten times and at least 45 days without a significant loss in its activity are the indicators of its good operational and storage stability. Moreover, TCA can be applicable to tap water, providing a promising tool for pesticides detection.

Originality/value - This is the first time to use the in situ analytical technique that can improve the performance of optical enzyme sensor provided to control the pesticide residue better with respect to traditional techniques. The effect of organic solvents on the performance of optical enzyme biosensor was investigated. Inhibition kinetic of the solvents rarely encountered in literature was also studied besides the $\mathrm{pH}$ and temperature tolerance of the optical biosensor.
\end{abstract}

Keywords Tyrosinase biosensor, Organophosphate pesticide, Parathion-methyl, Adsorption

Paper type Research paper

\section{Introduction}

One of the most important problems in the agricultural industry is to protect the food products from pesticides and herbicides. Thirty-eight per cent of the pesticides used all over the world are the organophosphorus ones because of their effective insecticidal activity (Bao et al., 2015) and the most commonly used one is parathion-methyl with high toxicity level (Yan et al., 2015; Sharma et al., 2009). Their residues on the food are harmful to human health and the ecological balance. Therefore, the extensive and insensible use of pesticides in agriculture increases the requirement for fast methods in residue analysis (Kim et al., 2008).

Chromatographic techniques such as gas chromatography, High performance liquid chromatography or coupled ones (GC-MS) are currently used as standard methods to detect pesticide residues on the food product. Despite some advantages such as high sensitivity, reliability and precision, these techniques are expensive, time-consuming, and are not easily adapted to in-field analysis (Solna et al., 2005). Biosensor

The current issue and full text archive of this journal is available on Emerald Insight at: www.emeraldinsight.com/0260-2288.htm

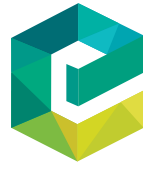

Sensor Review

39/4 (2019) 604-611

(C) Emerald Publishing Limited [ISSN 0260-2288]

[DOI 10.1108/SR-10-2018-0242] technology could be a reliable and promising alternative to the standard methods applied for detection of pesticide residue with advantages such as ease of use, provision of both real-time and in situ monitoring (Asal et al., 2018). Enzymatic biosensors have been developed by using organophosphorus hydrolase (OPH), alkaline phosphatase, ascorbate oxidase, acid phosphatase, butyrylcholinesterase, methyl parathion hydrolase $(\mathrm{MPH})$, acetylcholinesterase $(\mathrm{AChE})$ and tyrosinase (Du et al., 2007) for the detection of pesticides. Various analytical techniques such as a novel optical biosensor based on methyl parathion hydrolase immobilized by metal-chelate affinity (Lan et al., 2012), a new fluorescence probing strategy based on $\mathrm{N}$-doped carbon dots and methyl parathion hydrolase (Song et al., 2017), using Flavobacterium sp. whole cells adsorbed on glass fiber filters as disposable biocomponent (Kumar et al., 2006), carbon nanotube/organophosphorus hydrolase electrochemical biosensor (Deo et al., 2005), novel fluorescence probing strategy (Yan et al., 2015) and electrochemically reduced graphene oxide modified electrode (Jeyapragasam et al., 2013), were developed for detection of parathion-methyl. AChE-based biosensors for pesticide detection have also been extensively investigated in past decades (Zhou et al., 2013). For instance, Xue et al. (2012) immobilized the acetylcholinesterase via biocompatible

Received 1 October 2018

Revised 8 January 2019

Accepted 3 March 2019 
interface of silk fibroin for detection of parathion-methyl. Recently, as an alternative to AChE, tyrosinase enzyme attracts much attention because of its lower cost, more accessibility and without a need to reactivation (Yang et al., 2010).

In this study, the irreversible inhibition of tyrosinase enzyme will be first used to develop a simple, optical biosensor to detect "parathion-methyl" as a model pesticide.

Tyrosinase enzyme is a monooxygenase having monophenolase and diphenolase activity strictly dependent on its molecular structure. Immobilized tyrosinase finds application area including pharmaceutical drug production, pro-drug therapy for melanoma, antibody microarrays, detoxification of phenolic compounds and the detection of phenols (Aytar and Bakir, 2008).

Factors such as the nature and concentration of the enzyme and the substrate, $\mathrm{pH}$, temperature, organic solvents, heavy metals, chelating agents and external factors (irradiation and shear stress) are effective on the enzyme activity (Illanes, 2008; Missen et al., 1999). One of the most important factors among them is organic solvents for which enzymes show limited tolerance. Therefore, it is necessary to consider the influence of different solvents on enzyme activity, as well as to carefully choose the applied solvent. Proton concentration of the solution as another factor can affect the distribution of charges in the active site which may prevent proper conformation of the enzyme, binding of the substrates and/or catalysis of the enzyme reaction. Temperature is also an important factor to inactivate the enzyme. Adverse conditions of these factors can reduce or destroy its biological activity by distorting the proper active site configuration (Illanes, 2008; Yoruk and Marshall, 2003; Drauz and Waldmann, 2002). Consequently, the medium $\mathrm{pH}$, temperature and solvent concentration must be controlled and optimized to obtain high enzyme activity. To this end, a great deal of research has been conducted toward the development of enzyme immobilization (Buerk, 1993).

The development of ideal enzyme biosensor was influenced by choice of the sensor type. Spectrophotometric sensing has the advantage to be fast, easily manageable and moreover cheap in performance (Walz and Schwack, 2007). The other significant factors are the nature of the enzyme, immobilization techniques and supports (Nade et al., 2003). Organic-synthetic polymers such as polyamides, nylon, polyacrylamide and polyethylene; organic biopolymers such as silk, starch and agarose and inorganic materials such as clays and metals have been used as support (Drauz and Waldmann, 2002). Chitosan has been widely used for enzyme immobilization contains $-\mathrm{NH}_{2}$ and $-\mathrm{OH}$ groups. This material is preferable because of its excellent biocompatibility, nontoxicity, low cost, easyhandling and high mechanical strength (Krajewska, 2004). It is also transparent and available to study with most of the optical detection methods, which are based on changes in the absorbed light and used more frequently in the enzyme assay (Eisenthal and Danson, 2002).

In this study, tyrosinase immobilized chitosan films were prepared as an optical enzyme biosensors (TCA) for the detection of parathion-methyl, a model pesticide. The performance of the sensors was investigated by measuring their activities with respect to $\mathrm{pH}$, temperature, organic solvent tolerance, storage and operational stabilities. The inhibition mechanisms exerted by organic solvents and parathion-methyl rarely encountered in literature were also investigated by characterizing the apparent kinetic parameters of the enzymecatalyzed reaction. Therefore, a novel and cost-effective biosensor was designed by simple preparation method for detection of "parathion-methyl" pose to public health and the environment. This is the first time to use the in situ analytical technique that can improve the performance of optical enzyme sensor provided to control the pesticide residue better with respect to traditional techniques.

\section{Materials and methods}

\subsection{Reagent}

Tyrosinase from mushroom (T3824) with $25 \mathrm{KU}$, catechol (C9510), chitosan (448869), di-sodium hydrogen phosphate $\left(\mathrm{Na}_{2} \mathrm{HPO}_{4}\right)$, sodium di-hydrogen phosphate monohydrate $\left(\mathrm{NaH}_{2} \mathrm{PO}_{4} \cdot \mathrm{H}_{2} \mathrm{O}\right)$, parathion-methyl, hydrochloric acid $(\mathrm{HCl})$ and organic solvents such as ethanol, methanol, isopropyl alcohol, acetone and acetonitrile were used. All reagents were of analytical grade and supplied by Merck or Sigma-Aldrich. All aqueous solutions were prepared with ultra-pure water $(18.2 \mathrm{M} \Omega \mathrm{cm})$.

\subsection{Preparation of the solutions}

The phosphate buffer (pH: 6.5), tyrosinase (activity: $5370 \mathrm{U} / \mathrm{mg}$ ), chitosan, catechol, organic solvent and pesticide solutions were used in this study, as outlined in Table I. A total of $50 \mathrm{mM}$ phosphate buffer solution (PBS) was used for the preparation of tyrosinase, catechol and organic solvents solutions.

\subsection{Preparation and characterization of the films}

The glass rods were coated with tyrosinase immobilized chitosan film to prepare an optical enzyme sensor (TCA). Initially, the glass rods were ultrasonically cleaned with the ethanol-water mixture and then rinsed with ultra-pure water. Chitosan solution (prepared in $0.3 \mathrm{M} \mathrm{HCl}$ ) was dropped on the square surface $(0.8 \mathrm{~cm} \times 0.8 \mathrm{~cm})$ of the cleaned glass rods and dried at $60^{\circ} \mathrm{C}$ for $1 \mathrm{~h}$ to prepare the chitosan (C) film. To prepare the TCA film, tyrosinase solutions (1-10 $\mu 1$ ) was dropped on the Film C, dried for $2 \mathrm{~h}$ at room temperature and then immersed in PBS $(3 \mathrm{ml})$ for $30 \mathrm{~min}$ to release the nonimmobilized tyrosinase from the film surface. Thus the amount of enzyme immobilized on the film $\left(\mathrm{E}_{\mathrm{im}}\right)$ can be calculated as equation (1):

$$
\mathrm{E}_{\mathrm{im}}=\mathrm{E}_{\mathrm{i}}-\mathrm{E}_{\mathrm{w}}
$$

where $\mathrm{E}_{\mathrm{i}}$ and $\mathrm{E}_{\mathrm{w}}$ are the initial (loaded) and the released amounts of the enzyme, respectively.

Sensor components (C and TCA films) were also characterized by using AFM (MMSPM Nanoscope IV) in tapping mode and FTIR spectrophotometer (SHIMADZU $8400 S$ ). The FTIR spectra were recorded in the range of 4,000 to $400 \mathrm{~cm}^{-1}$ on $\mathrm{KBr}$ discs prepared by using the films ( $2 \mathrm{mg}$ ) and $\mathrm{KBr}(148 \mathrm{mg})$.

\subsection{Enzyme assay}

Ultraviolet (UV)-visible spectrophotometer (Perkin Elmer Lambda 45) was used to follow the formation of product "o-quinone" at pH 6.5 and at $25^{\circ} \mathrm{C}$. The analysis was started 
Table I The solutions used in this study

\begin{tabular}{lcl}
\hline Solutions & Concentrations & Preparation \\
\hline $\begin{array}{l}\text { Phosphate buffer at pH: } \\
6.5 \text { ( PBS) }\end{array}$ & $50 \mathrm{mM}$ & $\begin{array}{l}\text { Using } \mathrm{Na}_{2} \mathrm{HPO}_{4} \text { and } \\
\mathrm{NaH}_{2} \mathrm{PO}_{4} \cdot \mathrm{H}_{2} \mathrm{O}\end{array}$ \\
$\begin{array}{l}\text { Tyrosinase (activity: } \\
5370 \mathrm{U} / \mathrm{mg})\end{array}$ & $4.7 \mathrm{mg} / \mathrm{ml}$ & In PBS \\
$\begin{array}{l}\text { Catechol } \\
\text { Chitosan }\end{array}$ & $0.01-2 \mathrm{mM}$ & In PBS \\
$\begin{array}{l}\text { Organic solvents } \\
\text { Pesticide (parathion- }\end{array}$ & $20 \mathrm{mg} / \mathrm{ml}$ & In $\mathrm{HCl}(0.3 \mathrm{M})$ \\
methyl) & $1-20 \% \mathrm{v} / \mathrm{v}$ & In PBS \\
\hline
\end{tabular}

while TCA was introduced into the stirring reaction media $(1,000 \mathrm{rpm})$. Therein, it is possible to monitor the initial formation of o-quinone by preventing any time delay (in situ analysis).

Enzyme activity was calculated by Beer-Lambert relationship at $390 \mathrm{~nm}$ absorbance $\left(\varepsilon_{390}=1417 \mathrm{M}^{-1} \mathrm{~cm}^{-1}\right)$ for $1 \mathrm{~min}$ (Waite, 1976) [equation (2)]:

$$
\frac{d P}{d t}=\frac{d A}{d t} \frac{1}{\varepsilon l}
$$

where $\varepsilon$ is extinction coefficient of o-quinone, $l$ is path-length $(1 \mathrm{~cm})$ and $\mathrm{dA} / \mathrm{dt}$ is the change in absorbance at $390 \mathrm{~nm}$. The effects of $\mathrm{pH}$ (in the range of 5 to 8), temperature (in the range of 15 to $40^{\circ} \mathrm{C}$ ), organic solvents (in the range of 1 to 20 per cent $\mathrm{v} / \mathrm{v})$ and parathion-methyl (0.034-51.5 $\mu \mathrm{M})$ on enzyme activity were investigated. For optimum conditions, the relative enzyme activity was used as the ratio of activity to maximum activity.

Sensory performances such as linearity, sensitivity (the slope of the linear range) and limit of detection (LOD) were tested. LOD was also calculated by using the equation (3):

$$
L O D=\frac{\left(3 \cdot S_{y / x}\right)}{a}
$$

where $a$ is the sensitivity of the method and $S_{y / x}$ is the standard deviation of the fit. The operational and storage stabilities of TCA were also determined by measuring the activity of the sensor for ten uses and for a given time of storage, respectively. They were stored in PBS at $4^{\circ} \mathrm{C}$ when not in use.

\subsection{Reaction kinetics}

The reaction between the tyrosinase (E) and catechol solution (S) [equation (4)]:

$$
E+S \underset{k_{-1}}{\stackrel{k_{1}}{\leftrightarrow}} E S \stackrel{k_{2}}{\longrightarrow} E+P
$$

Conducted in a 3-ml quartz cuvette is expressed with Michaelis-Menten equation (Koenhen and Smolders, 1975):

$$
v=\frac{V_{m}[S]}{K_{m}+[S]}
$$

where $v$ and $V_{m}$ represent the production rates of o-quinone at any and maximum substrate concentrations [S], respectively.
The Michaelis constants, $\left.\mathrm{K}_{\mathrm{m}}\left(\left(\mathrm{k}_{-1}+\mathrm{k}_{2}\right) / \mathrm{k}_{1}\right)\right)$ and $V_{m}$, was obtained from the reaction velocity $[\nu]$ vs substrate concentration [S] curve by using experimental data obtained at catechol concentrations in the range of 0.01 to $2 \mathrm{mM}$. The data obtained with three replicates were fitted into the model equation (5) by minimizing the error:

$$
\text { Error: }\left[\sum\left(v_{\exp }-v_{c a l}\right)\right]
$$

The presence of pesticide or organic solvents results in the inhibition of enzyme [E] or the enzyme substrate [ES] forming [EI] or [ES.I]), respectively [equation(7)]:

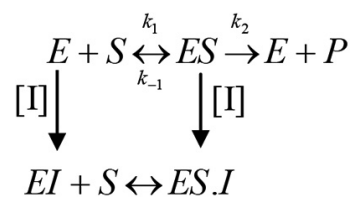

The inhibition mechanism can be estimated by following the production rate of o-quinone $(\mathrm{dP} / \mathrm{dt})$.

\section{Results and discussions}

\subsection{Characterization of the films}

The morphology of the film C and TCA prepared with enzyme immobilization was depicted in Figure 1. The film $\mathrm{C}$ displays uniform porous network structure, which makes the film available for loading the enzyme [Figure 1(a)]. When tyrosinase was immobilized on the film $\mathrm{C}$, the aggregates of the enzyme molecules exhibit island-like structures [Figure 1(b)], which may facilitate the specific reaction between the substrate and

Figure 1 AFM images of (a) C and (b) TCA

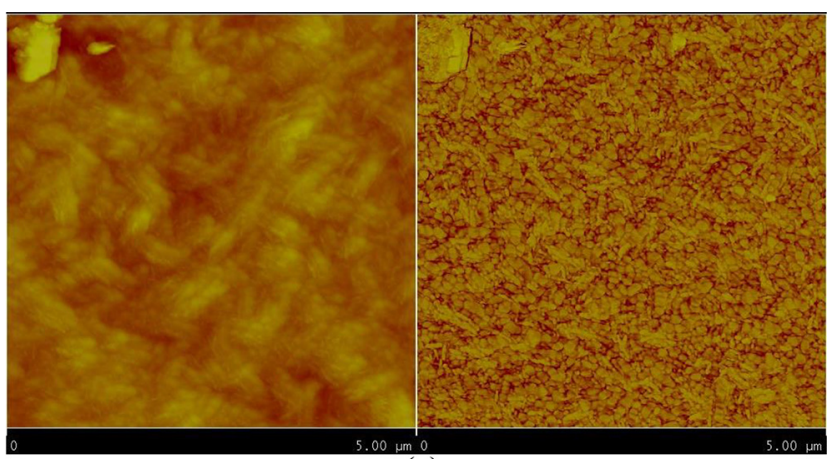

(a)

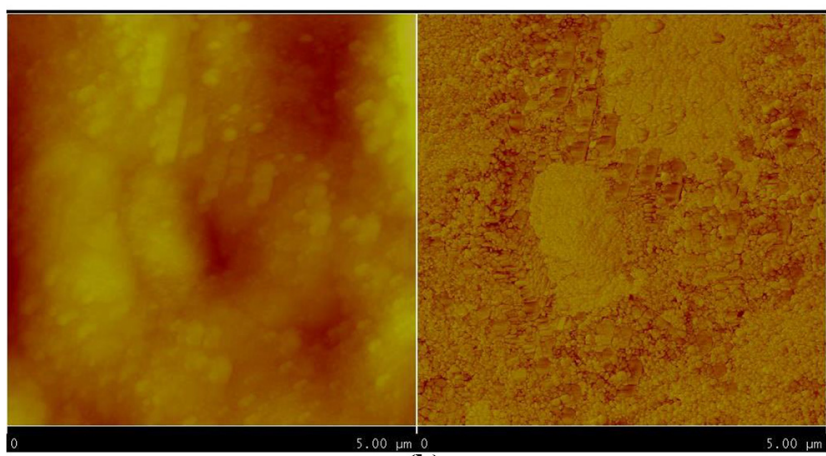

(b) 
the enzyme, resulting in a good response for the biosensor applications as stated by Cabaj and Soloducho (2011).

The FTIR spectra of the powder chitosan, the film $\mathrm{C}$ and TCA were depicted in Figure 2. Amide I $(C=O)$, amide II (N-H bending and C-N stretching), symmetric $\mathrm{NH}_{3}{ }^{+}$bending and $\mathrm{CH}_{3}$ deformation vibrations related with the FTIR figure are given in Table II.

When chitosan powder was dissolved in $\mathrm{HCl}$ solution ( $3 \mathrm{M}$ ), hydrogen ions bind to amide I and amide II groups in the molecular chain of the chitosan. The attachment of hydrogen ions to amide I caused to peak shift from the wavenumber of $1,650 \mathrm{~cm}^{-1}$ to $1,630 \mathrm{~cm}^{-1}$ [Figure 2(a)] depending on the deformation of antisymmetric $\mathrm{NH}_{3}{ }^{+}$vibrations. The disappearance of the weak band at $1,595 \mathrm{~cm}^{-1}$ and formation of the strong band at $1,520 \mathrm{~cm}^{-1}$ (contains the amide II, N-H bending vibration as well as the symmetric $-\mathrm{NH}_{3}{ }^{+}$ deformation) can be attributed to the attachment of hydrogen

Figure 2 FTIR spectra of (a) chitosan powder " - - -" and C "—_ " (b) C" _ " and TCA "....."

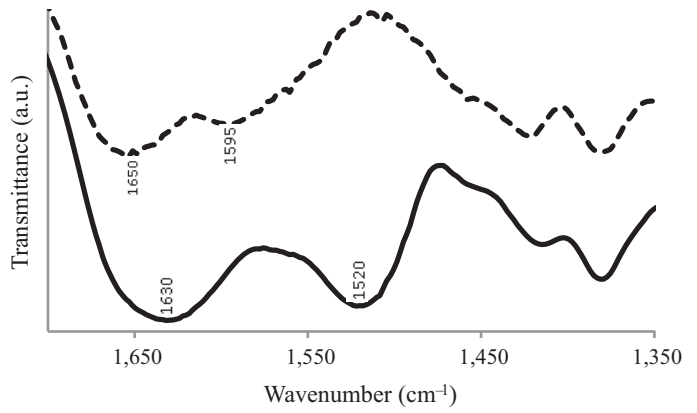

(a)
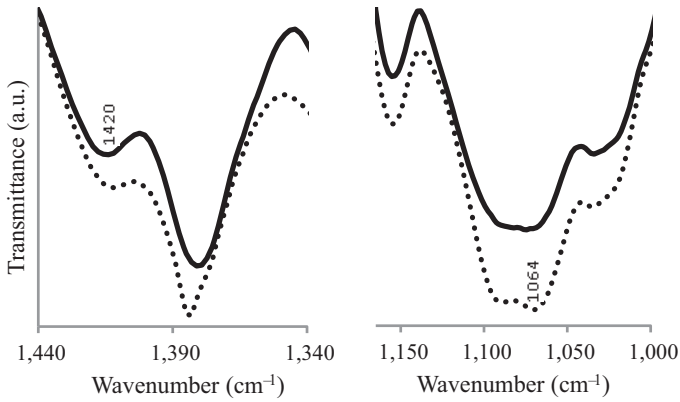

(b)

Table II FTIR spectra and their assignments

\begin{tabular}{ll}
\hline Vibration $\left(\mathrm{cm}^{-1}\right)$ & Assignment \\
\hline $3,290-3,422$ & $\mathrm{O}-\mathrm{H}$ and $\mathrm{N}-\mathrm{H}$ stretch \\
$2,864-2,915$ & $\mathrm{C}-\mathrm{H}$ stretch \\
$1,700-1,600$ & Amide I $\mathrm{C}=\mathrm{O})$ \\
$1,620-1,500$ & Amide II $(\mathrm{N}-\mathrm{H}$ bending and $\mathrm{C}-\mathrm{N}$ stretching) \\
1,420 & Symmetric $-\mathrm{NH}_{3}^{+}$bending \\
1,375 & $\mathrm{CH}_{3}$ symmetrical deformation \\
$1,073-1,031$ & $\mathrm{C}-\mathrm{O}$ group or $\mathrm{C}-\mathrm{C}$ group of amino acid side
\end{tabular}

Sources: Kumar et al. (1999); Wang et al. (2008); Zhou et al. (2006) ions to amide II site (Lawrie et al., 2007). Figure 2(b) shows the change in the spectrum of chitosan film with enzyme immobilization. Decrease in intensity at $1,420 \mathrm{~cm}^{-1}$ band, representing symmetric $-\mathrm{NH}_{3}{ }^{+}$bending, associated with protonated residues of the chitosan film was observed with immobilization. This was consistent with the formation of an electrostatic bond between the enzyme and the amino group of the chitosan film. The occurrence of the band at $1,064 \mathrm{~cm}^{-1}$, attributable to various $\mathrm{C}-\mathrm{C}$ modes of amino acid side chains (Sampaio et al., 2005), was also distinctive.

\subsection{Effect of immobilization on the enzyme activity}

The tyrosinase immobilized chitosan film was used as an optical enzyme sensor to detect the parathion-methyl. As shown in Figure 3(a), non-immobilized enzyme $\left(E_{w}\right)$ was removed from the film surface being washed with PBS for

Figure 3 (a) The enzyme released from the film for different loaded enzyme amount, $E_{i}(\mu \mathrm{g}) / \mu \mathrm{g}$ support: $(\mathrm{x}) 0.1765$, (A) 0.1175, 0.0785, (+) 0.0387, (-) 0.0295; (b) change in immobilized enzyme amount $\left(E_{i m}\right)$ with loaded enzyme amount $\left(E_{i}\right)$ for TCA and $(c)$ change in the activity depending on immobilized enzyme amount for TCA

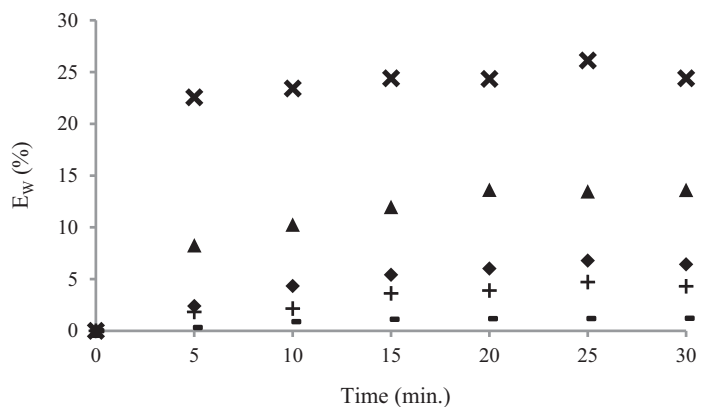

(a)

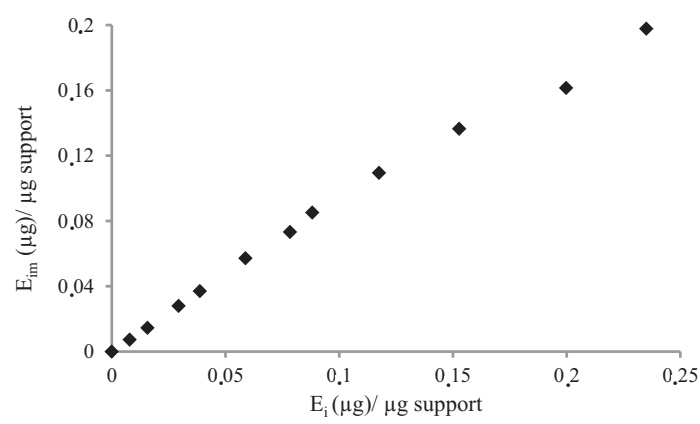

(b)

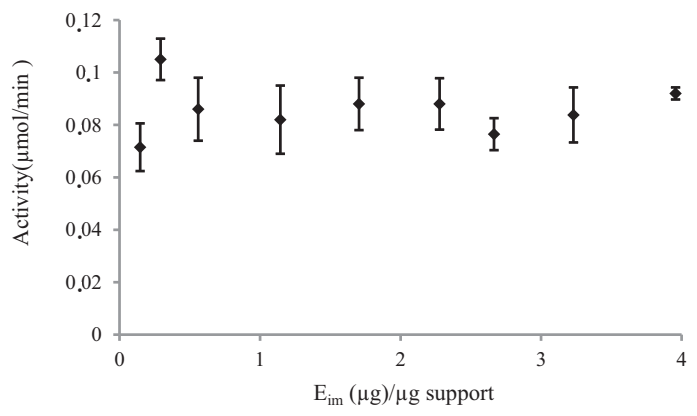

(c) 
$30 \mathrm{~min}$. Besides, increase in the released per cent of the loaded enzyme $\left(E_{w}\right.$ per cent $\left.=100 \times E_{w} / E_{i}\right)$ with increasing the loaded amount $\left(E_{i}\right)$ explains that tyrosinase was adsorbed on the film surface only [Figure 3(a)].

The amount of immobilized enzyme $\left(E_{i m}\right)$ linearly increases with increasing the loaded enzyme amount $\left(E_{i}\right)$ for TCA as depicted in Figure 3(b). However, the activity of the optical enzyme sensors was not also significantly affected by the amount of immobilized enzyme, as shown in Figure 3(c). Therefore, it is not meaningful to load high enzyme concentration and minimum amount of enzyme $\left(E_{i m}=\right.$

Figure 4 The effect of (a) $\mathrm{pH}$ on the activity of free $(\bullet)$ and immobilized ( $\square$ )enzyme at $25^{\circ} \mathrm{C}$, (b) temperature on the activity of free $(\diamond)$ and immobilized ( $\square$ ) enzyme at pH: 6.5 and (c) organic solvents on immobilized tyrosinase activity (pH: 6.5 and $\left.\mathrm{T}: 27^{\circ} \mathrm{C}\right)$

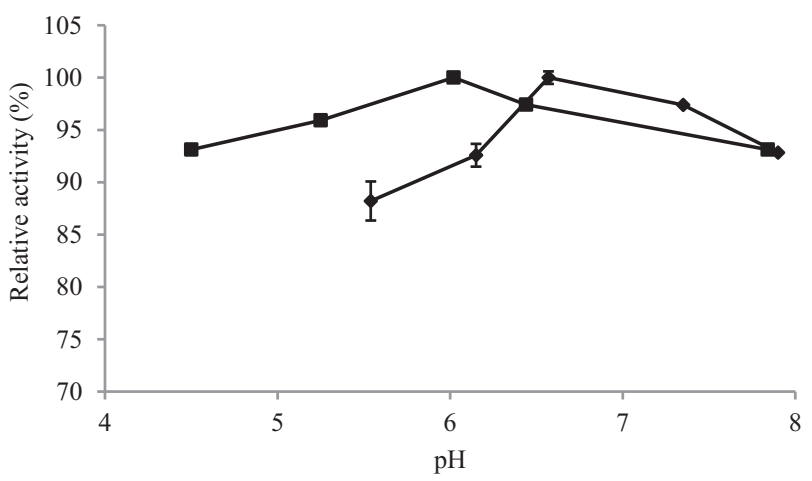

(a)

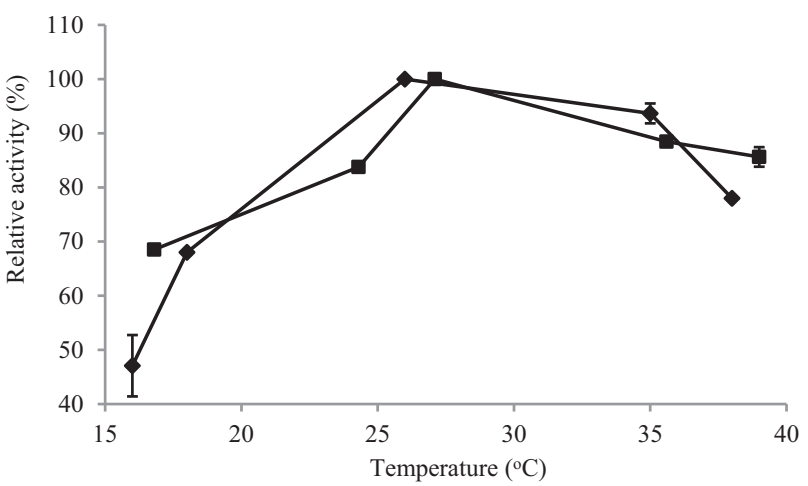

(b)

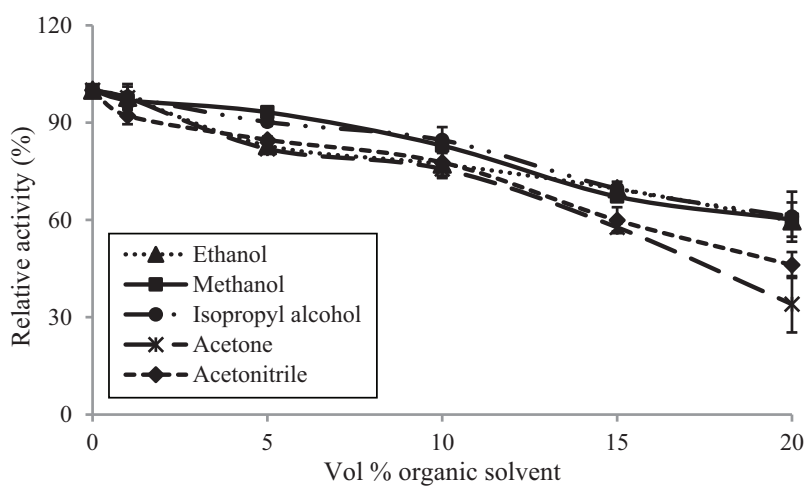

(c)

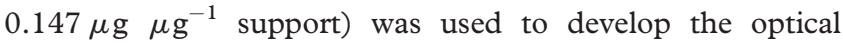
enzyme sensor.

As seen in Figure 4(a), the maximum relative activity was observed at about $\mathrm{pH}$ of 6.57 and 6.02 for free and immobilized enzyme, respectively. The slight shift in maximum $\mathrm{pH}$ toward the acidic region arises from amino groups in chitosan. Because these groups responsible for enzyme immobilization are protonated toward the acidic region. On the other hand, toward basic medium, deactivation was expected due to conformational changes in the tyrosinase active site as stated by Yoruk and Marshall (2003. Figure 4(b) shows the effect of temperature on free and immobilized tyrosinase at $\mathrm{pH}$ 6.5. The optimum temperature for the highest activity was observed at $26^{\circ} \mathrm{C}$ and $27^{\circ} \mathrm{C}$ for the free and the immobilized enzyme, respectively. The decrease in activity at lower or higher temperature than the optimum one arises from a decrease in the kinetic energy of the reactant molecules or thermal denaturation, respectively. The effect of polar solvents, namely, ethanol, methanol, isopropyl alcohol, acetone and acetonitrile on immobilized tyrosinase activity was also investigated. For all solvents, the relative immobilized tyrosinase activity was decreased with increasing concentrations [Figure 4(c)] because of the destruction of active enzyme conformation by the displacement of bound water molecules with solvents as stated by Walz and Schwack (2007).

\subsection{Kinetic analysis and stability of the optical enzymes sensor (TCA)}

The Michaelis-Menten model equation [equation (5)] was used to clarify the inhibition mechanism exerted by the solvents (Table III). $\mathrm{V}_{\mathrm{m}}$ values of immobilized tyrosinase are lower when compared with free enzyme's value. This could be attributed to the changing in the enzyme structure by the immobilization, and increasing diffusional resistance for the substrate to reach the enzyme (Illanes, 2008; Drauz and Waldmann, 2002). The inhibition mechanisms exerted by the organic solvents were characterized by comparing $\mathrm{K}_{\mathrm{m}}$ and $\mathrm{V}_{\mathrm{m}}$ values, as depicted in Table III.

The polar protic solvent (ethanol, methanol and isopropyl alcohol) did not show any inhibition effect on free tyrosinase activity due to lower molecular polarity (Walz and Schwack, 2007). The net effect of acetone and acetonitrile on free tyrosinase enzyme is to increase $\mathrm{K}_{\mathrm{m}}$, whereas o-quinone production rate at maximum substrate concentration is constant. For the immobilized tyrosinase, the organic solvents inhibited the enzyme activity via different mechanisms: Acetone directly reacted with enzyme $(E)$ to produce enzyme inhibitor (EI) complex (competitive inhibition), whereas methanol and acetonitrile reacted with $(E S)$ to produce enzyme substrate inhibitor (ES.I) complex (uncompetitive inhibition). Ethanol and isopropyl alcohol are the inhibitors that lead to the production of (ES.I) from (EI) (noncompetitive inhibition) as shown in inhibition reaction mechanisms [equation (7)]. On the other hand, decrease in enzyme activity was higher [Figure 4(c)] in the presence of polar aprotic solvents (acetone and acetonitrile) due to strip essential water from the enzyme molecules depending on higher molecular polarity with respect to protic ones (Walz and Schwack, 2007). Isopropyl alcohol was chosen among them to prepare the solution for parathionmethyl detection. 
Table III Kinetic parameters of free and immobilized tyrosinase in organic solvent (10\%) containing aqueous media

\begin{tabular}{|c|c|c|c|c|c|c|c|c|}
\hline \multirow[b]{2}{*}{ Solvent } & \multicolumn{4}{|c|}{ Free tyrosinase } & \multicolumn{4}{|c|}{ Immobilized tyrosinase } \\
\hline & $\begin{array}{c}\mathbf{V}_{\mathrm{m}} \\
(\mu \mathrm{mol} / \mathrm{min})\end{array}$ & $\begin{array}{c}\mathrm{K}_{\mathrm{m}} \\
(\mathrm{mM})\end{array}$ & Error & $\begin{array}{c}\text { Inhibition } \\
\text { type* }\end{array}$ & $\begin{array}{c}\mathbf{V}_{\mathbf{m}} \\
(\mu \mathrm{mol} / \mathrm{min})\end{array}$ & $\begin{array}{c}\mathrm{K}_{\mathrm{m}} \\
(\mathrm{mM}))\end{array}$ & Error & $\begin{array}{c}\text { Inhibition } \\
\text { type }\end{array}$ \\
\hline Solvent free & 0.67 & 0.56 & 0.023 & n.d. & 0.134 & 0.311 & 0.040 & n.d. \\
\hline Ethanol & 0.67 & 0.53 & 0.015 & n.d. & 0.108 & 0.314 & 0.021 & $\mathrm{~N}$ \\
\hline Methanol & 0.68 & 0.54 & 0.021 & n.d. & 0.094 & 0.273 & 0.036 & $\mathrm{U}$ \\
\hline Isopropyl alcohol & 0.65 & 0.50 & 0.056 & n.d. & 0.095 & 0.311 & 0.031 & $\mathrm{~N}$ \\
\hline Acetone & 0.68 & 1.07 & 0.017 & $\mathrm{C}$ & 0.132 & 0.369 & 0.053 & C \\
\hline Acetonitrile & 0.66 & 0.76 & 0.023 & $\mathrm{C}$ & 0.099 & 0.256 & 0.032 & $\mathrm{U}$ \\
\hline
\end{tabular}

The repetitive use is a very significant parameter when developing new enzyme sensor. Figure 5(a) shows the change in activity with the number of use (the operational stability) for TCA. The sensor shows good operational stability and there was no significant decrease in the activity even after the 10th use. Figure 5(b) shows the change in storage stability of free enzyme and TCA. As can be seen from the Figure, significant decrease in free enzyme activity was observed while activity of TCA remained unaltered approximately after 45 days. This result shows that immobilization enhances the storage stability of the enzyme which could be attributed to the higher conformational stability.

Figure 5 (a) Operational stability of TCA and (b) storage stability of free $(\bullet)$ and immobilized $(\square)$ enzyme

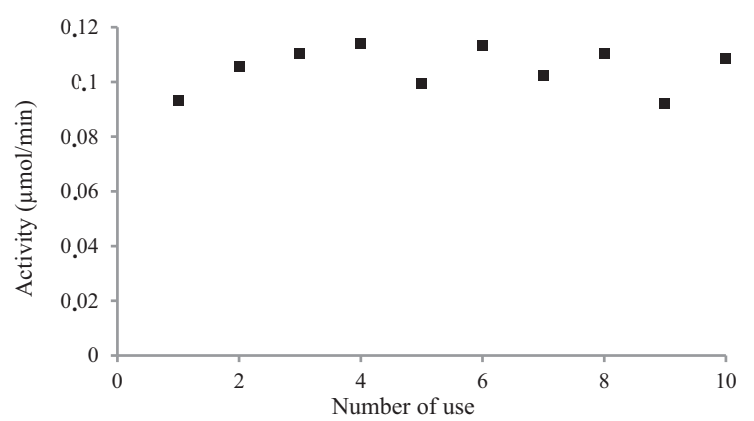

(a)

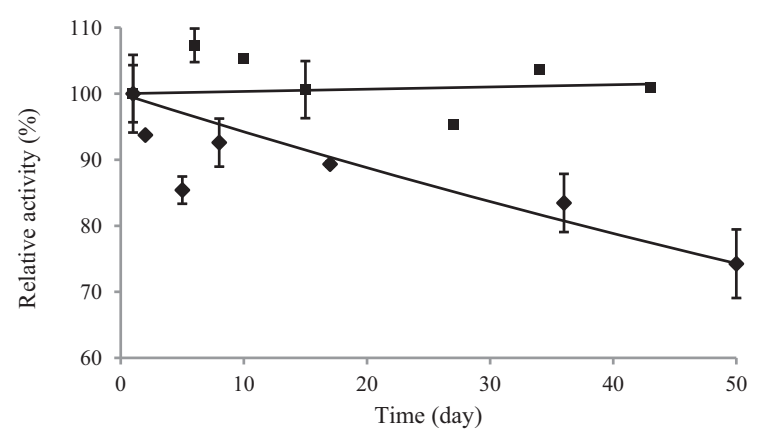

(b)

\subsection{Determination of parathion-methyl by TCA}

Depending on inhibition mechanism, the developed optical enzyme biosensor was tested for detection of parathion-methyl. Relative enzyme activity of TCA decreased up to 74.7 per cent due to noncompetitive inhibition as understood from the kinetic parameters of the enzyme catalyzed reaction (Table IV).

As seen from Figure 6, the activity of TCA linearly decreases up to $1.03 \mu \mathrm{M}$ parathion-methyl concentration with high regression coefficient $\left(R^{2}=0.99\right)$ and sensitivity $(13.22 \mathrm{nmol}$ $\min ^{-1} \mu \mathrm{M}^{-1}$ ). LOD value of TCA (calculated as $0.159 \mu \mathrm{m}$ from equation (3) lower than biosensors reported in the literature (Table $\mathrm{V}$ ) was found in the range of maximum residue limit (MRL: 0.038-0.190 $\mu \mathrm{m}$ ) according to European Commission Pesticide Database (2012).

To test the accuracy of reading, the tap water polluted with parathion-methyl at a concentration of 0.172 and $1.03 \mu \mathrm{M}$ was also measured and found as $0.161^{ \pm 0.048}$ and $1.03^{ \pm 0.055} \mu \mathrm{M}$, respectively. These results also demonstrated low matrix effect (possible organic material, salts, heavy metals, some ions, some other pesticides and microorganisms that can be possible in tap water content) on the biosensor response.

\section{Conclusions}

In this study, tyrosinase immobilized chitosan films were developed as optical biosensor (TCA) to determine the parathion-methyl, model pesticide. Tyrosinase enzyme was successfully immobilized to support as a results of electrostatic interactions. A total of $0.147 \mu \mathrm{g} \mathrm{g}^{-1}$ of enzyme/support ratio was sufficient to observe the maximum activity. Even approximately fivefold decrease in maximum activity was observed while $\mathrm{pH}$, temperature and storage stability of the enzyme were enhanced by immobilizing the tyrosinase to chitosan by providing structural rigidity and appropriate flexibility. Moreover, TCA could be used ten times total without significant change in its activity. Isopropyl alcohol seems to be most appropriate organic solvent to solve the parathion-methyl. TCA sensor could detect the parathion-methyl concentration with the linear range of 0 to $1.03 \mu \mathrm{M}$ at low detection limit, high sensitivity and high correlation coefficient. These results indicate that the developed sensor is a promising candidate in the determination of other types of pesticide residue. 
Table IV Response characteristic of TCA in free and parathion-methyl containing media

\begin{tabular}{|c|c|c|c|c|c|c|}
\hline Medium & $\mathrm{Km}(\mathrm{mM})$ & $\mathrm{Vm}(\mu \mathrm{mol} / \mathrm{min})$ & $R^{2}$ & Error & Inhibition type* & Relative activity (\%) \\
\hline Parathion-methyl free & 0.311 & 0.095 & 0.969 & 0.031 & n.d & 100 \\
\hline With Parathion-methyl & 0.310 & 0.081 & 0.976 & 0.025 & $\mathrm{~N}$ & $74.7^{ \pm 1.3}$ \\
\hline
\end{tabular}

Figure 6 Activity of TCA in the presence of parathion-methyl

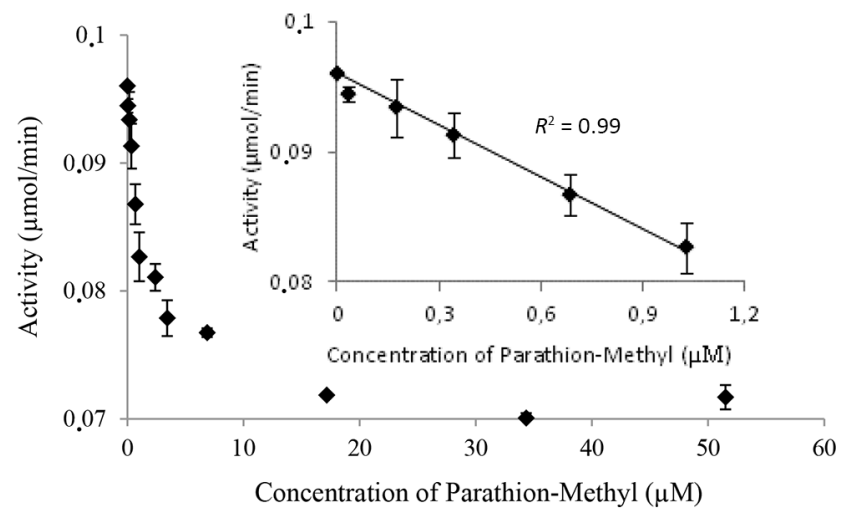

Note: Inset is the linear range of the curve

Table V Sensing performance of TCA in parathion-methyl containing media

\begin{tabular}{|c|c|c|c|}
\hline Method & $R^{2}$ & $\operatorname{LOD}(\mu \mathrm{M})$ & Reference \\
\hline $\begin{array}{l}\text { Optical tyrosinase } \\
\text { biosensor }\end{array}$ & 0.990 & 0.159 & This work \\
\hline MPH-based biosensor & 0.991 & 4.000 & Lan et al. (2012) \\
\hline $\begin{array}{l}\text { NCDs/MPH-based } \\
\text { biosensor }\end{array}$ & 0.993 & 0.338 & Song et al. (2017) \\
\hline $\begin{array}{l}\text { Optical microbial } \\
\text { biosensor }\end{array}$ & 0.998 & 0.300 & Kumar et al. (2006) \\
\hline OPH-based biosensor & n.d. & 0.800 & Deo et al. (2005) \\
\hline CdTe QDs/CTAB & 0.993 & 0.068 & Yan et al. (2015) \\
\hline ERGO & 0.990 & 0.887 & $\begin{array}{l}\text { Jeyapragasam et al. } \\
\text { (2013) }\end{array}$ \\
\hline $\begin{array}{l}\text { AChE/MWNTs-based } \\
\text { biosensor }\end{array}$ & 0.998 & 0.500 & Xue et al. (2012) \\
\hline OPH-based biosensor & 0.998 & 1.000 & Mulchandani et al. (2001) \\
\hline $\begin{array}{l}\text { Pd/MWCNTs-based } \\
\text { biosensor }\end{array}$ & 0.999 & 0.190 & Huang et al. (2010) \\
\hline $\begin{array}{l}\text { Au/MWCNTs-based } \\
\text { biosensor }\end{array}$ & 0.997 & 0.190 & Ma and Zhang (2011) \\
\hline Colorimetric sensor & n.d. & 0.423 & Sharma et al. (2009) \\
\hline \multicolumn{4}{|c|}{$\begin{array}{l}\text { Notes: MPH: Methyl parathion hydrolase, NCDs: N-doped carbon dots, } \\
\text { OPH: organophosphorus hydrolase, CdTe QDs: CdTe quantum dots, CTAB: } \\
\text { cetyltrimethylammonium bromide, ERGO: Electrochemically Reduced } \\
\text { Graphene Oxide, n.d.: not determined }\end{array}$} \\
\hline
\end{tabular}

\section{References}

Asal, M., Özen, Ö., Şahinler, M. and Polatoğlu, İ. (2018), "Recent developments in enzyme, DNA and immuno-based biosensors", Sensors, Vol. 18 No. 6, p. 1924.
Aytar, B.S. and Bakir, U. (2008), "Preparation of cross-linked tyrosinase aggregates", Process Biochemistry, Vol. 43 No. 2, pp. 125-131.

Bao, J., Hou, C., Chen, M., Li, J., Huo, D., Yang, M., Luo, X. and Lei, Y. (2015), "Plant esterase-chitosan/gold nanoparticles-graphene nanosheet composite-based biosensor for the ultrasensitive detection of organophosphate pesticides", Fournal of Agricultural and Food Chemistry, Vol. 63 No. 47, pp. 10319-10326.

Buerk, D.G. (1993), Biosensors; Theory and Applications, Technomic Publishing.

Cabaj, J. and Soloducho, J. (2011), "Hybrid film biosensor for phenolic compounds detection", in Somerset, V. (Ed.), Environmental Biosensors, InTech, Rijeka, Chapter 10, pp. 213-236.

Deo, R.P., Wang, J., Block, I., Mulchandani, A., Joshi, K.A., Trojanowicz, M., Scholz, F., Chen, W. and Lin, Y. (2005), "Determination of organophosphate pesticides at a carbon nanotube/organophosphorus hydrolase electrochemical biosensor", Analytica Chimica Acta, Vol. 530 No. 2, pp. 185-189.

Drauz, K. and Waldmann, H. (2002), Enzyme Catalysis in Organic Synthesis, 2nd ed., Wiley-VCH.

Du, D., Cai, J., Song, D. and Zhang, A. (2007), "Rapid determination of triazophos using acetylcholinesterase biosensor based on sol-gel interface assembling multiwall carbon nanotubes", Fournal of Applied Electrochemistry, Vol. 37 No. 8, pp. 893-898.

Eisenthal, R. and Danson, M.J. (2002), Enzyme Assays, 2nd ed., Oxword University Press, Oxford.

European Commission Pesticide Database (2012), available at: https://eur-lex.europa.eu/legal-content/MT/TXT/HTML/?uri= CELEX:32012R0899\&from=EN\#ntr ${ }^{\star \star}$-L_2012273MT. 01000401-E0003

Huang, B., Zhang, W.D., Chen, C.H. and Yu, Y.X. (2010), "Electrochemical determination of methyl parathion at a $\mathrm{Pd} /$ MWCNTs-modified electrode", Microchimica Acta, Vol. 171 Nos $1 / 2$, pp. 57-62.

Illanes, A. (2008), Enzyme Biocatalysis Principles and Applications, Springer.

Jeyapragasam, T., Saraswathi, R., Chen, S.M. and Lou, B.S. (2013), "Detection of Methyl Parathion at an electrochemically reduced graphene oxide (ERGO) modified electrode", International fournal of Electrochemical Science, Vol. 8 No. 11, pp. 12354-12366.

Kim, G.Y., Shim, J., Kang, M.S. and Moon, S.H. (2008), "Optimized coverage of gold nanoparticles at tyrosinase electrode for measurement of a pesticide in various water samples", fournal of Hazardous Materials, Vol. 156 Nos 1/3, pp. 141-147.

Koenhen, D.M. and Smolders, C.A. (1975), "The determination of solubility parameters of solvents and polymers by means of 
correlations with other physical quantities", fournal of Applied Polymer Science, Vol. 19 No. 4, pp. 1163-1179.

Krajewska, B. (2004), "Application of chitin- and chitosanbased materials for enzyme immobilizations: a review", Enzyme and Microbial Technology, Vol. 35 Nos 2/3, pp. 126-139.

Kumar, j., Jha, S.K. and D'Souza, S.F. (2006), “Optical microbial biosensor for detection of methyl parathion pesticide using Flavobacterium sp. whole cells adsorbed on glass fiber filters as disposable biocomponent", Biosensors and Bioelectronics, Vol. 21 No. 11, pp. 2100 -2105.

Kumar, G., Smith, P.J. and Payne, G.F. (1999), "Enzymatic grafting of a natural product onto chitosan to confer water solubility under basic conditions", Biotechnology and Bioengineering, Vol. 63 No. 2, pp. 154-165.

Lan, W., Chen, G., Cui, F., Tan, F., Liu, R. and Yushupujiang, M. (2012), "Development of a novel optical biosensor for detection of organophoshorus pesticides based on methyl parathion hydrolase immobilized by metal-chelate affinity”, Sensors, Vol. 12 No. 7, pp. 8477-8490.

Lawrie, G., Keen, I., Drew, B., Temple, A.C., Rintoul, L., Fredericks, P. and Grøndahl, L. (2007), "Interactions between alginate and chitosan biopolymers characterized using FTIR and XPS", Biomacromolecules, Vol. 8 No. 8, pp. 2533-2541.

Ma, J.C. and Zhang, W.D. (2011), "Gold nanoparticle-coated multiwall carbon nanotube-modified electrode for electrochemical determination of methyl parathion", Microchimica Acta, Vol. 175 Nos 3/4, pp. 309-314.

Missen, R.W., Mims, C.A. and Saville, B.A. (1999), Introduction to Chemical Reaction Engineering and Kinetics, John Wiley \& Sons, New York, NY.

Mulchandani, P., Chen, W., Mulchandani, A., Wang, J. and Chen, L. (2001), "Amperometric microbial biosensor for direct determination of organophosphate pesticides using recombinant microorganism with surface expressed organophosphorus hydrolase”, Biosensors and Bioelectronics, Vol. 16 Nos 7/8, pp. 433-437.

Nade, C.D., D'Amico, A., Soncini, G., Ferraxio, I. and Zen, M. (2003), "Sensors and microsystems", Proceedings of the 8th Italian Conference Trento.

Sampaio, S., Taddei, P., Monti, P., Buchert, J. and Freddi, G. (2005), "Enzymatic grafting of chitosan onto Bombyx mori silk fibroin: kinetic and IR vibrational studies", fournal of Biotechnology, Vol. 116 No. 1, pp. 21-33.

Sharma, A.K., Gaur, M.S., Sharma, P., Tiwari, R.K. and Bhadoria, S. (2009), "Development of colorimetric sensor instrument for quantitative analysis of methyl parathion", Sensor Review, Vol. 29 No. 1, pp. 70-74.

Solna, R., Sapelnikova, S., Skladal, P., Winther-Nielsen, M., Carlsson, C., Emneus, J. and Ruzgas, T. (2005),
"Multienzyme electrochemical array sensor for determination of phenols and pesticides", Talanta, Vol. 65 No. 2, pp. 349-357.

Song, W., Zhang, H.J., Liu, Y.H., Ren, C.L. and Chen, H.L. (2017), "A new fluorescence probing strategy for the detection of parathion-methyl based on $\mathrm{N}$-doped carbon dots and methyl parathion hydrolase", Chinese Chemical Letters, Vol. 28 No. 8, pp. 1675-1680.

Waite, J.H. (1976), "Calculating extinction coefficients for enzymatically produced o-quinones", Analytical Biochemistry, Vol. 75 No. 1, pp. 211-218.

Walz, I. and Schwack, W. (2007), "Cutinase inhibition by means of insecticidal organophosphates and carbamates part 1: basics in development of a new enzyme assay", European Food Research and Technology, Vol. 225 Nos 3/4, pp. 593-601.

Wang, Y., Li, B., Zhou, Y. and Jia, D. (2008), "Chitosaninduced synthesis of magnetite nanoparticles via iron ions assembly", Polymers for Advanced Technologies, Vol. 19 No. 9, pp. 1256-1261.

Xue, R., Kang, T.F., Lu, L.P. and Cheng, S.Y. (2012), "Immobilization of acetylcholinesterase via biocompatible interface of silk fibroin for detection of organophosphate and carbamate pesticides", Applied Surface Science, Vol. 258 No. 16, pp. 6040-6045.

Yan, X., Li, H.X., Wang, X.Y. and Su, X.G. (2015), “A novel fluorescence probing strategy for the determination of parathion-methyl", Talanta, Vol. 131, pp. 88-94.

Yang, L.M., Huo, D.Q., Hou, C.J., He, K., Lv, F.J., Fa, H.B. and Luo, X.G. (2010), "Purification of plant-esterase in PEG1000/ $\mathrm{NaH}_{2} \mathrm{PO}_{4}$ aqueous two-phase system by a twostep extraction", Process Biochem, Vol. 45 No. 10, pp. 1664-1671.

Yoruk, R. and Marshall, M.R. (2003), "Physicochemical properties and function of plant polyphenol oxidase: a review", Fournal of Food Biochemistry, Vol. 27 No. 5, pp. 361-422.

Zhou, H., Liu, L., Yin, K., Liu, S. and Li, G. (2006), "Electrochemical investigation on the catalytic ability of tyrosinase with the effect of nano titanium dioxide", Electrochemistry Communications, Vol. 8 No. 7, pp. 1168-1172.

Zhou, Q., Yang, L., Wang, G.C. and Yang, Y. (2013), "Acetylcholinesterase biosensor based on $\mathrm{SnO}_{2}$ nanoparticles-carboxylic graphemenafion modified electrode for detection of pesticides", Biosens. Bioelectron, Vol. 49, pp. 25-31.

\section{Corresponding author}

Ilker Polatoğlu can be contacted at: ilker.polatoglu@cbu. edu.tr 